\title{
Beneficiation Studies of a Rare Earth Ore from the Olserum Deposit
}

\author{
Xiaosheng Yang1, Neea Heino², Lassi Pakkanen ${ }^{2}$ \\ ${ }^{1}$ GTK Mintec, Geological Survey of Finland, Outokumpu, Finland \\ ${ }^{2}$ Geological Survey of Finland, Espoo, Finland \\ Email: jason.yang@gtk.fi, neea.heino@gtk.fi, lassi.pakkanen@gtk.fi
}

How to cite this paper: Yang, X.S., Heino, N. and Pakkanen, L. (2019) Beneficiation Studies of a Rare Earth Ore from the Olserum Deposit. Natural Resources, 10, 346357.

https://doi.org/10.4236/nr.2019.109023

Received: August 15, 2019

Accepted: September 14, 2019

Published: September 17, 2019

Copyright $\odot 2019$ by author(s) and Scientific Research Publishing Inc. This work is licensed under the Creative Commons Attribution International License (CC BY 4.0).

http://creativecommons.org/licenses/by/4.0/

c) (i) Open Access

\begin{abstract}
The Olserum deposit located in Sweden hosts an indicated mineral resource of 4.5 million tonnes at $0.6 \%$ total rare earth oxides (TREO), exhibiting a relatively high proportion of heavy rare earth elements (HREE). The mineralogy and beneficiation of a composite drill core sample from the Olserum deposit were studied. Monazite and xenotime were found by the mineralogical analyses to be the target minerals for beneficiation of REEs and most (96.9\%) of REEs in the ore are carried by monazite (68.5\%) and xenotime (28.4\%). Because xenotime carries $84.7 \%$ of heavy REEs (Y, Gd, Dy) in the ore it is more valuable mineral than monazite. A beneficiation process was developed which includes grinding, wet low intensity magnetic separation (WLIMS) for removal of magnetite and REEs flotation consisting of one stage of roughing and two stages of cleaning. Selective flotation collector of REE minerals and suitable grinding size of feed material were determined by testwork. The REE concentrate and tailings were chemically and mineralogically characterized. The studies of process mineralogy showed that the REE-bearing minerals, monazite and xenotime, and apatite were successfully enriched from the concentrations of $0.6 \%, 0.31 \%$ and $2.6 \%$ in the feed to those of $17.0 \%, 8.9 \%$ and $65.0 \%$ in the concentrate with the recoveries of $79.0 \%, 81.3 \%$ and $71.0 \%$, respectively.
\end{abstract}

\section{Keywords}

The Olserum Deposit, Rare Earth Minerals, Flotation

\section{Introduction}

Rare earth elements (REEs) normally refer to 15 lanthanides plus chemically similar ytrrium $(\mathrm{Y})$ and scandium $(\mathrm{Sc})$. REEs typically split into two sub-groups, the light rare earth elements (LREE) which includes Sc, La, Ce, Pr, Nd, Pm, Sm 
and $\mathrm{Eu}$, and the heavy rare earth elements (HREE) which includes $\mathrm{Y}, \mathrm{Gd}, \mathrm{Tb}$, $\mathrm{Dy}, \mathrm{Ho}, \mathrm{Er}, \mathrm{Tm}, \mathrm{Yb}$ and $\mathrm{Lu}$. The Olserum deposit located in Sweden comprises lower grade placer material with higher grade apatite-magnetite veins and hosts an indicated mineral resource of 4.5 million tonnes at $0.6 \%$ total rare earth oxides (TREO), with $34 \%$ of that being heavy rare earth oxides (HREO) [1]. The mineralization was studied by Andersson et al. (2018) [2]. At early stage, hightemperature REEs were characterized by abundant monazite-(Ce) and xenotime- $(\mathrm{Y})$ coexisting with fluorapatite and subordinate amounts of (Y, REEs, $\mathrm{U}$, $\mathrm{Fe})-(\mathrm{Nb}, \mathrm{Ta})$ oxides. During a subsequent stage, allanite-(Ce) and ferriallanite-(Ce) were formed locally, partly resulting from the breakdown of primary monazite-(Ce). Alteration of allanite-(Ce) or ferriallanite-(Ce) to bastnäsite-(Ce) and minor synchysite-(Ce) at lower temperatures represented the latest stage of REE mineral formation.

The mineralogy and beneficiation of the ore were firstly studied by GTK Mintec in the EURARE project for a composite drill core sample. The Olserum is considerably smaller than the NorraKärr deposit. However, rare earth elements (REEs) are hosted by xenotime and monazite, both of which have well established processing pathways, and meanwhile, the Olserum has a high contribution of the high value critical REEs (dysprosium (Dy), yttrium (Y), neodymium $(\mathrm{Nd})$ and terbium $(\mathrm{Tb})$ ), which provide a unique advantage for its exploration [3]. In this paper, flotation of the REE-bearing minerals in the Olserum ore was studied.

\section{Materials and Methods}

A drill core composite sample weighted $110 \mathrm{~kg}$ from the Olserum deposit was sent to GTK Mintec in Outokumpu, Finland. The sample was crushed to -1.5 $\mathrm{mm}$ and homogenized, and split to $1.5 \mathrm{~kg}$ subsamples. One subsample of $1.5 \mathrm{~kg}$ was further split into $100 \mathrm{~g}$ samples for chemical and mineralogical analyses.

Sodium peroxide plus sodium hydroxide digestion was used for determination of REEs by ICP-MS technique which was performed by Labtium Oy in Finland. The limits of detection (LODs) of the ICP-MS for REEs are shown in Table 1.

Quantitative mineralogical studies were carried out by using a mineral liberation analyzer (MLA) and an electron probe micro analyzer (EPMA).

The modal mineralogy, i.e. the percentages of the mineral components, the mineral liberation and the grain size distribution of REE-bearing minerals were measured using MLA (a FEI MLA Quanta 600 system) at GTK Mintec. Minerals were identified mostly based on Energy Dispersive X-Ray Spectroscopy (EDS) analyses. Using the EDS analysis the composition of a certain mineral was determined and the composition was compared to the composition of the mineral in MinIdent mineralogy database and a mineralogical book [4]. Also the EDS spectrum was compared to the spectra in the databases of MLA.

For determining the chemical compositions of REE minerals in the sample a CAMECA SX100 EPMA at the Geological Survey of Finland in Espoo, Finland was used. Analytical results were corrected using the PAP on-line correction 
programme [5]. The limits of detection (LODs) of the EPMA for REEs and radioactive elements, $\mathrm{U}$ and $\mathrm{Th}$, are shown in Table 2.

The subsamples of $1.5 \mathrm{~kg}$ with the size of $-1.5 \mathrm{~mm}$ were ground at a laboratory rod mill as the feeds for beneficiation experiments. The relationships between grinding size and time were determined by testing. The concentration of solid for grinding was $60 \% \mathrm{wt}$ using tap water at the room temperature $\left(20^{\circ} \mathrm{C}\right.$ $\left.23^{\circ} \mathrm{C}\right)$.

According to the mineralogical properties of the sample the flowsheet of magnetic separation of magnetite followed by REE-bearing minerals flotation was designed. Flotation experiments were carried out using a GTK laboratory flotation machine. The flotation cells with the volumes of 1.5, 2.5 and 4.0 liters were used. Tap water was used for conditioning and flotation at the room temperature. Wet low intensity magnetic separation (WLIMS) experiments were performed using a Sala laboratory magnetic separator (wet low intensity roller type) with the magnetic field of 0.07 Tesla.

\section{Results and Discussion}

\subsection{Chemical and Mineralogical Analyses}

Chemical analysis results are shown in Table 3. It is seen that the content of total REEs (TREE) in the Olserum composite ore is only $0.54 \%$, but the rate of valuable heavy REEs (HREE) is quite high, that is, $37 \%$ of REEs in the ore are HREE. The radioactive elements, $U$ and Th, have contents of $242 \mathrm{mg} / \mathrm{kg}$ and 81 $\mathrm{mg} / \mathrm{kg}$, respectively.

Total 28 minerals were identified by MLA. The modal mineralogy is presented in Table 4. It is revealed that this is a high silicate ore with the silicate concentration of $94 \%$. In addition, a relatively high content of magnetite $(2.29 \%)$ was recognized.

Four minerals were identified by MLA and EPMA to bear REEs, two phosphate minerals monazite-(Ce) and xenotime with the contents of $0.61 \%$ and $0.31 \%$, respectively, one silicate mineral allanite with the content of $0.07 \%$, and one niobium oxide mineral pyrochlore with the content of $0.01 \%$.

The chemical compositions of the four REE-bearing minerals were measured by EPMA. The results (Table 5) show that compositions of REO in these four REE-bearing minerals are 65.4\% (monazite), 53.4\% (xenotime), 25.1\% (allanite) and $3.3 \%$ (pyrochlore). Monazite and xenotime have high compositions of REO, especially xenotime also being high in the concentration of heavy REO including $\mathrm{Y}_{2} \mathrm{O}_{3}, \mathrm{Gd}_{2} \mathrm{O}_{3}$ and $\mathrm{Dy}_{2} \mathrm{O}_{3}$.

Based on the data of modal mineralogy and the REO compositions of REEbearing minerals the concentrations of REEs (measured by REOs) in the ore were calculated and shown in Table 6 . It is seen that the calculated concentrations based on the mineralogical analyses of MLA and EPMA are very close to the chemical analysis data by ICP-MS. The distributions of total REEs (measured by REOs) in the REE-bearing minerals are: $68.5 \%$ in monazite, $28.4 \%$ in xeno- 
time, $3.0 \%$ in allanite and $0.1 \%$ in pyrochloe, respectively. The distributions of heavy REEs (Y, Gd and Dy) in the REE-bearing minerals are: $14.5 \%$ in monazite, $84.7 \%$ in xenotime, $0.6 \%$ in allanite and $0.2 \%$ in pyrochlore, respectively.

Table 1. The limits of detection (LODs) of the ICP-MS for REEs (mg/kg).

\begin{tabular}{cccccccc}
\hline $\mathrm{La}$ & $\mathrm{Ce}$ & $\mathrm{Pr}$ & $\mathrm{Nd}$ & $\mathrm{Sm}$ & $\mathrm{Eu}$ & $\mathrm{Gd}$ & $\mathrm{Tb}$ \\
\hline 0.1 & 0.1 & 0.1 & 0.2 & 0.2 & 0.05 & 0.05 & 0.1 \\
$\mathrm{Dy}$ & $\mathrm{Ho}$ & $\mathrm{Er}$ & $\mathrm{Tm}$ & $\mathrm{Yb}$ & $\mathrm{Lu}$ & $\mathrm{Y}$ & $\mathrm{Sc}$ \\
0.1 & 0.1 & 0.05 & 0.1 & 0.05 & 0.1 & 1 & 1 \\
\hline
\end{tabular}

Table 2. The limits of detection (LODs) of the EPMA for REEs (mg/kg).

\begin{tabular}{ccccccccccc}
\hline La & Ce & Pr & Nd & Sm & Gd & Dy & Y & Sc & U & Th \\
\hline 2016 & 2365 & 3122 & 4547 & 3571 & 3366 & 2368 & 1711 & 529 & 3225 & 2770 \\
\hline
\end{tabular}

Table 3. Chemical analysis results $(\mathrm{mg} / \mathrm{kg})$.

\begin{tabular}{cccccccc}
\hline La & $\mathrm{Ce}$ & $\mathrm{Pr}$ & $\mathrm{Nd}$ & $\mathrm{Sm}$ & $\mathrm{Eu}$ & $\mathrm{Gd}$ & $\mathrm{Tb}$ \\
\hline 621 & 1590 & 202 & 796 & 187 & 3 & 209 & 36 \\
$\mathrm{Dy}$ & $\mathrm{Ho}$ & $\mathrm{Er}$ & $\mathrm{Tm}$ & $\mathrm{Yb}$ & $\mathrm{Lu}$ & $\mathrm{Y}$ & $\mathrm{Sc}$ \\
217 & 45 & 132 & 19 & 123 & 0 & 1210 & 0 \\
$\mathrm{ZrO}_{2}$ & $\mathrm{U}$ & $\mathrm{Th}$ & $\mathrm{C}$ & & TREE & HREE/LREE \\
$\%$ & & $\%$ & & wt $\%$ & & $37 / 63$ \\
0 & 242 & 82 & 0.08 & 5390 & 0.54 & & \\
\hline
\end{tabular}

Table 4. Modal mineralogy of the Olserum ore (wt\%).

\begin{tabular}{|c|c|c|c|}
\hline \multicolumn{2}{|c|}{ Silicate } & \multicolumn{2}{|c|}{93.94} \\
\hline Quartz & 47.89 & Chamosite & 0.31 \\
\hline Albite & 11.9 & Illite & 0.92 \\
\hline K_feldspar & 0.54 & Andalustite & 2.12 \\
\hline Cummingtonite & 0.9 & Staurolite & 1.05 \\
\hline Gedrite & 3.96 & Tourmaline & 0.25 \\
\hline Biotite & 19.66 & Allanite $^{\mathrm{a}}$ & 0.07 \\
\hline Muscovite & 0.29 & Zircon & 0.02 \\
\hline Clinochlore & 0.65 & & \\
\hline \multicolumn{2}{|c|}{ Carbonate } & \multicolumn{2}{|c|}{0.10} \\
\hline Calcite & 0.04 & Siderite & 0.06 \\
\hline \multicolumn{2}{|c|}{ Phosphate } & \multicolumn{2}{|c|}{3.56} \\
\hline Apatite & 2.59 & Xenotime $^{\mathrm{a}}$ & 0.31 \\
\hline Monazite- $(\mathrm{Ce})^{\mathrm{a}}$ & 0.61 & Wagnerite & 0.05 \\
\hline \multicolumn{2}{|c|}{ Other } & \multicolumn{2}{|c|}{2.34} \\
\hline Magnetite & 2.29 & Pyrochlore $^{\mathrm{a}}$ & 0.01 \\
\hline Ilmenite & 0.04 & Masuyite & 0.00 \\
\hline Unclassified & & 0.06 & \\
\hline \multicolumn{2}{|c|}{ Total } & \multicolumn{2}{|c|}{100.00} \\
\hline
\end{tabular}

${ }^{\mathrm{a}} \mathrm{REE}-$ bearing minerals. 
Table 5. The individual concentrations of REEs and $U$ and Th in all the REE-bearing phases: allanite, monazite, xenotime and pyrochlore by EPMA (mg/kg) (measured by REOs, $\mathrm{UO}_{2}$ and $\left.\mathrm{ThO}_{2}\right)^{\mathrm{a}}$.

\begin{tabular}{ccccc}
\hline & Monazite & Xenotime & Allanite & Pyrochlore \\
\hline $\mathrm{UO}_{2}$ & 12,100 & 6200 & & 159,400 \\
$\mathrm{ThO}_{2}$ & 13,300 & n.d. & & 3200 \\
$\mathrm{La}_{2} \mathrm{O}_{3}$ & 114,000 & n.d. & 41,400 & n.d. \\
$\mathrm{Ce}_{2} \mathrm{O}_{3}$ & 311,700 & n.d. & 125,100 & n.d. \\
$\mathrm{Pr}_{2} \mathrm{O}_{3}$ & 32,400 & n.d. & 13,000 & n.d. \\
$\mathrm{Nd}_{2} \mathrm{O}_{3}$ & 124,600 & n.d. & 47,200 & n.d. \\
$\mathrm{Sm}_{2} \mathrm{O}_{3}$ & 25,100 & 7700 & 8800 & n.d. \\
$\mathrm{Y}_{2} \mathrm{O}_{3}$ & 20,300 & 410,500 & 8100 & 17,500 \\
$\mathrm{Gd}_{2} \mathrm{O}_{3}$ & 19,600 & 51,600 & 7000 & 8500 \\
$\mathrm{Dy}_{2} \mathrm{O}_{3}$ & 5900 & 63,800 & n.d & 7300 \\
$\mathrm{Total} \mathrm{REO}_{\mathrm{R} E O}$ & 653,700 & 533,600 & 250,600 & 33,300 \\
$\mathrm{HREO}^{2}$ & 45,800 & 525,900 & 15,100 & 33,300 \\
\hline
\end{tabular}

${ }^{a}$.d.: not detected.

Table 6. The concentrations of REOs, $\mathrm{UO}_{2}$ and $\mathrm{ThO}_{2}$ in the ore $(\mathrm{mg} / \mathrm{kg})^{\mathrm{a}}$.

\begin{tabular}{ccccccc}
\hline & Monazite & Xenotime & Allanite & Pyrochlore & $\begin{array}{c}\text { Total } \\
\text { (MLA-EPMA) }\end{array}$ & ICP-MS \\
\hline $\mathrm{UO}_{2}$ & 73.7 & 19.3 & & 15.9 & 109.0 & 274.5 \\
$\mathrm{ThO}_{2}$ & 81.2 & n.d. & & 0.3 & 81.5 & 92.2 \\
$\mathrm{La}_{2} \mathrm{O}_{3}$ & 695.1 & n.d. & 29.0 & n.d. & 724.1 & 728.3 \\
$\mathrm{Ce}_{2} \mathrm{O}_{3}$ & 1901.6 & n.d. & 87.5 & n.d. & 1989.1 & 1862.3 \\
$\mathrm{Pr}_{2} \mathrm{O}_{3}$ & 197.8 & n.d. & 9.1 & n.d. & 206.9 & 236.4 \\
$\mathrm{Nd}_{2} \mathrm{O}_{3}$ & 760.1 & n.d. & 33.0 & n.d. & 793.1 & 928.4 \\
$\mathrm{Sm}_{2} \mathrm{O}_{3}$ & 153.2 & 23.9 & 6.2 & n.d. & 183.4 & 216.8 \\
$\mathrm{Y}_{2} \mathrm{O}_{3}$ & 124.1 & 1272.5 & 5.7 & 1.7 & 1404.0 & 1536.6 \\
$\mathrm{Gd}_{2} \mathrm{O}_{3}$ & 119.5 & 160.0 & 4.9 & 0.8 & 285.2 & 240.9 \\
Dy $2 \mathrm{O}_{3}$ & 36.1 & 197.9 & n.d & 0.7 & 234.8 & 249.0 \\
Total REO & 3987.6 & 1654.5 & 175.4 & 3.3 & 5820.6 & 5998.9 \\
Distribution of & 68.5 & 28.4 & 3.0 & 0.1 & 100.0 & \\
TREO \% & & & & & & \\
Distribution of & 14.5 & 84.7 & 0.6 & 0.2 & 100.0 & \\
$\mathrm{HTREO}(\mathrm{Y}, \mathrm{Gd}$, & 14.5 & & & & & \\
Dy) \% & & & & & & \\
\hline
\end{tabular}

${ }^{a}$ n.d.: not detected.

\subsection{Target Minerals of REEs}

The concentrations of REOs in the ore (Table 6) show most (96.9\%) of REEs in the ore are carried by monazite $(68.5 \%)$ and xenotime $(28.4 \%)$. Thus, monazite and xenotime are the target minerals for beneficiation of REEs. Because xenotime carries $84.7 \%$ of heavy REEs (Y, Gd, Dy) in the ore it is more valuable mineral than monazite.

The MLA images of monazite and xenotime particles are shown in Figure 1. 
Single particles of monazite and xenotime are found in fine grain sizes but many monazite and xenotime particles are associated with other minerals mainly apatite and biotite etc. The grain size (80\% passing), the liberation degrees (90\% 95\% liberated) and associations of monazite and xenotime measured by MLA are shown in Table 7.
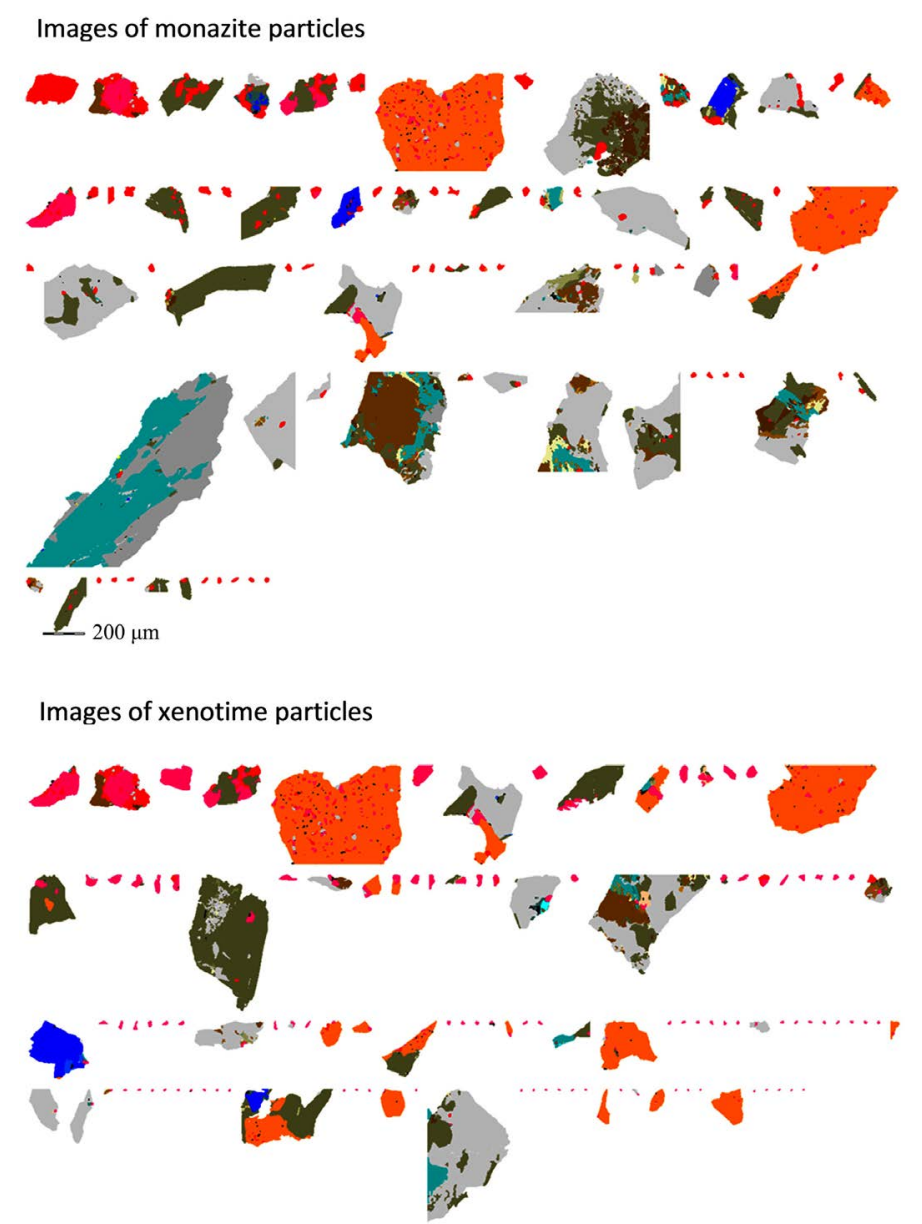

$-200 \mu \mathrm{m}$

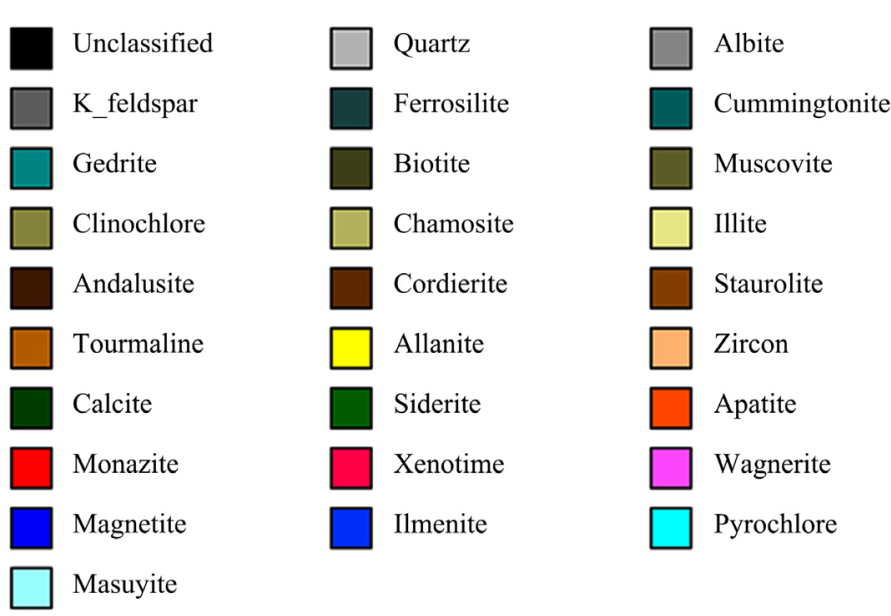

Figure 1. MLA images of monazite and xenotime particles. 
Table 7. Grain size, liberation and association of monazite and xenotime.

\begin{tabular}{|c|c|c|c|c|c|c|c|c|}
\hline & \multirow{2}{*}{$\begin{array}{c}\text { Grain size, } \\
\text { P80 } \mu \mathrm{m}\end{array}$} & \multirow{2}{*}{$\begin{array}{c}\text { Liberation \% } \\
(90 \%-95 \% \\
\text { liberated) }\end{array}$} & \multicolumn{6}{|c|}{ Association \% } \\
\hline & & & $\begin{array}{c}\text { Free } \\
\text { surface }\end{array}$ & Apatite & Biotite & Quartz & Monazite & Xenotime \\
\hline Monazite & 95 & 43 & 48.3 & 10.5 & 14.8 & 9.2 & & 5.0 \\
\hline Xenotime & 110 & 37 & 50.9 & 22.5 & 7.1 & 4.5 & 9.3 & \\
\hline
\end{tabular}

Table 7 shows that the grain sizes of monazite and xenotime are 95 and 110 $\mu \mathrm{m}$, respectively, which are appropriate sizes for flotation. The liberation degrees $(37 \%-43 \%)$ are quite low. The free surfaces of two minerals are about $50 \%$. The associated minerals are mainly apatite, biotite and quartz. Figure 1 shows that monazite and xenotime are associated with these minerals in very fine size.

\subsection{Development of Beneficiation Process}

The mineralogical analyses above show that monazite and xenotime are the target minerals of REEs in the ore. As phosphate minerals with suitable grain size (around $100 \mu \mathrm{m}$ ) for flotation they could be easily floated with fatty acids or hydroxamic acids as the collectors. For the crushed sample with size of $-1.5 \mathrm{~mm}$ the liberation degrees $(37 \%-43 \%)$ are quite low. Grinding is necessary for increasing their liberation degrees. Their highly association with apatite, biotite and quartz in very fine size would negatively influence beneficiation efficiency of REEs.

In the basis of preliminary experiments a beneficiation flowsheet was developed (Figure 2) which includes grinding, wet low intensity magnetic separation (WLIMS) for removal of magnetite and REEs flotation consisting of one stage of roughing and two stages of cleaning.

Aero 6494, an alkyl hydroxamate developed by CYTEC, was selected by testing as the collector of the REE-bearing minerals. Other conventional phosphate collectors including Na-oleate, EVRR (a fatty acid) mixed with OMC8191 (an emulgator), Aero 845 (a sulfosuccinamate reagent) and S-9849 (an alkyl hydroxamate) were also tested at the grinding size of $\mathrm{P} 80=75 \mu \mathrm{m}$ and neutral $\mathrm{pH}$. Comparing to other collectors Aero 6494 was found to be more selective for the REEs flotation measured by the recovery of REEs ( $\mathrm{La}, \mathrm{Ce}, \mathrm{Y}$ ) vs. the mass yield as shown in Figure 3. S-9849 was also a selective collector, but higher dosage was required comparing to Aero 6494 at the same recovery of REEs.

The effect of grinding size on the flotation performance of REEs is shown in Figure 4. In the range of grinding size $75 \mu \mathrm{m}$ to $180 \mu \mathrm{m}$ (P80) as the grinding size increasing the REEs (La, Ce, Y) grade of REEs concentrate increases but the REEs (La, Ce, Y) recovery decreases. To get a high recovery of REEs $(>90 \%)$ at rougher stage the material should be ground to (P80) $75 \mu \mathrm{m}$ to $120 \mu \mathrm{m}$.

\subsection{Characterizations of REE Concentrate and Tailings}

At the optimized conditions the REEs concentrate was obtained and assayed by 
XRF. The mineralogy of the REEs concentrate and the roughing tailings (Tail) was measured by MLA. Figure 5 and Figure 6 show that three main REEs, La, Ce and $\mathrm{Y}$, radioactive elements $\mathrm{Th}$ and $\mathrm{U}$, and phosphorus (measured by $\mathrm{P}_{2} \mathrm{O}_{5}$ ) were significantly enriched in the REEs concentrate and $\mathrm{Fe}, \mathrm{Si}$ and $\mathrm{Mg}$ as impurities were significantly removed.

The mineral grades of apatite, monazite, xenotime, silicate and others in the ore, concentrate and tailings are shown in Figure 7. It is seen that phosphates including monazite and xenotime were effectively enriched and silicates as the gangues were removed to the tailings. It is noted that apatite appears in the concentrate at a high grade (65\%). Separation of apatite from monazite and xenotime could increase the REE grade of the concentrate. High intensity magnetic separation or acid leaching would be effective approaches for further processing of the concentrate.

The mineral recoveries of apatite, monazite, xenotime, silicate and others in the concentrate, tailings and middling are shown in Figure 8. It is seen that although both monazite and xenotime had high recoveries (around 80\%) in the concentrate significant amounts of them $(14 \%-18 \%)$ were lost into the middling or the cleaning tailings. Further recovery of monazite and xenotime from the middling by flotation would be challenging because of high concentrations of oxides which could contaminate the flotation of phosphates and high associations of monazite and xenotime with these minerals. Regrinding of the middling may be required. As further investigation in the future a locked cycle test work combined with mineralogical analyses of the cleaning tailings should be performed to study the effect of returning the middling in the flotation process on the flotation performance of REEs.

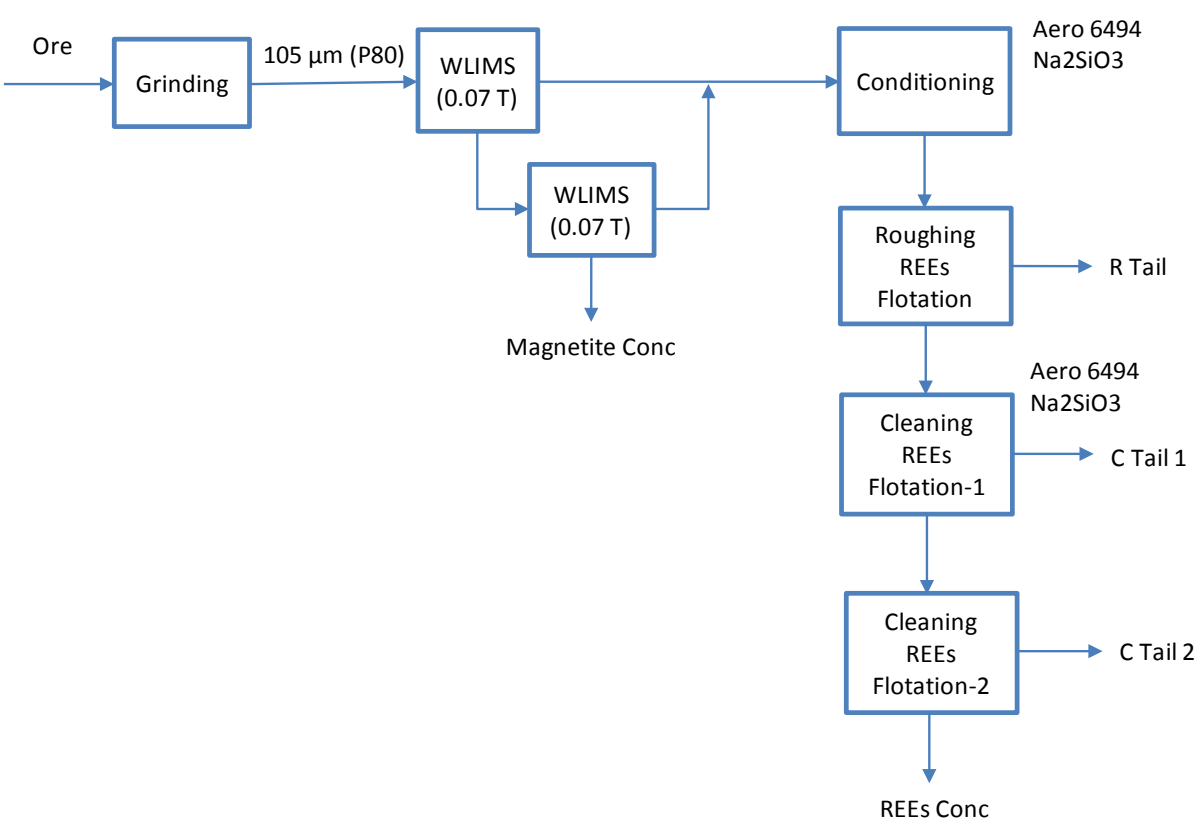

Figure 2. The beneficiation flowsheet for the Olserum ore. 


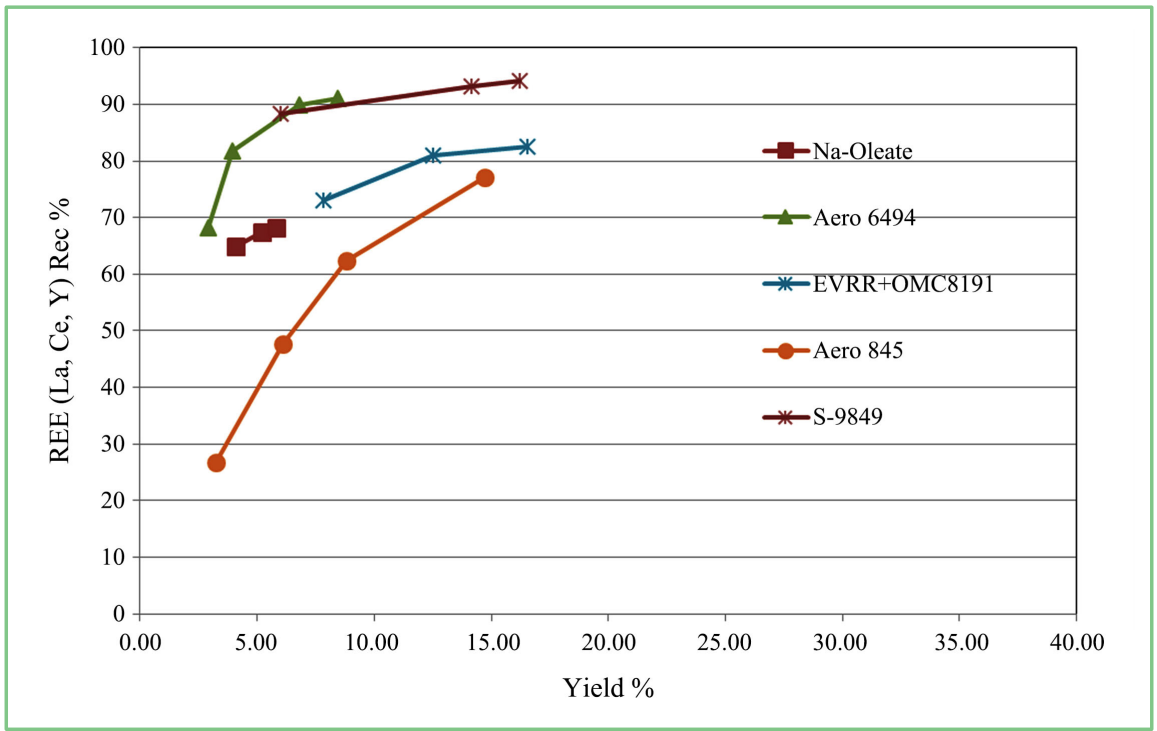

Figure 3. Effect of collector type on the flotation performance of REEs measured by REEs (La, Ce, Y) recovery vs. weight yield of the REEs concentrate (grinding size $75 \mu \mathrm{m}$ and neutral $\mathrm{pH})$.

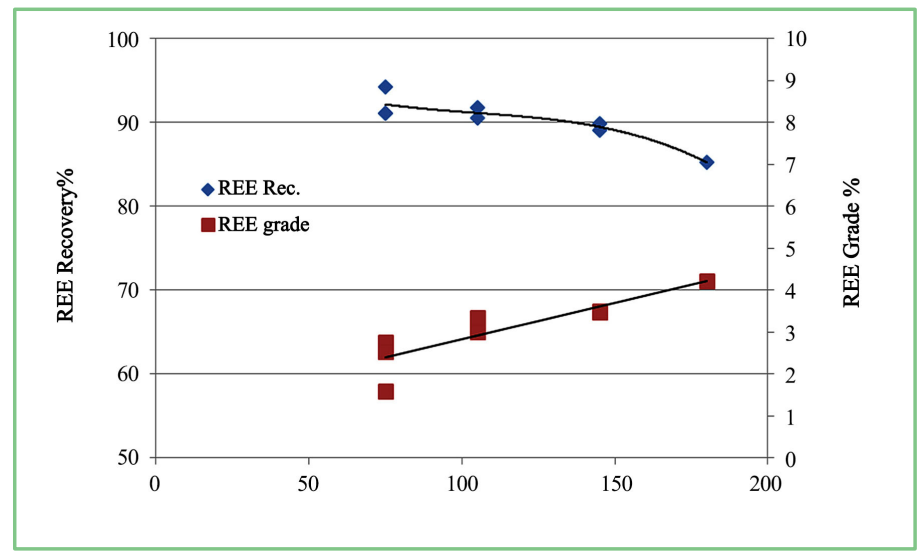

Figure 4. Effect of grinding size on the flotation performance of REEs measured by REEs (La, Ce, Y) grade and recovery of the REEs concentrate (with Aero 6494 as the collector at neutral pH).

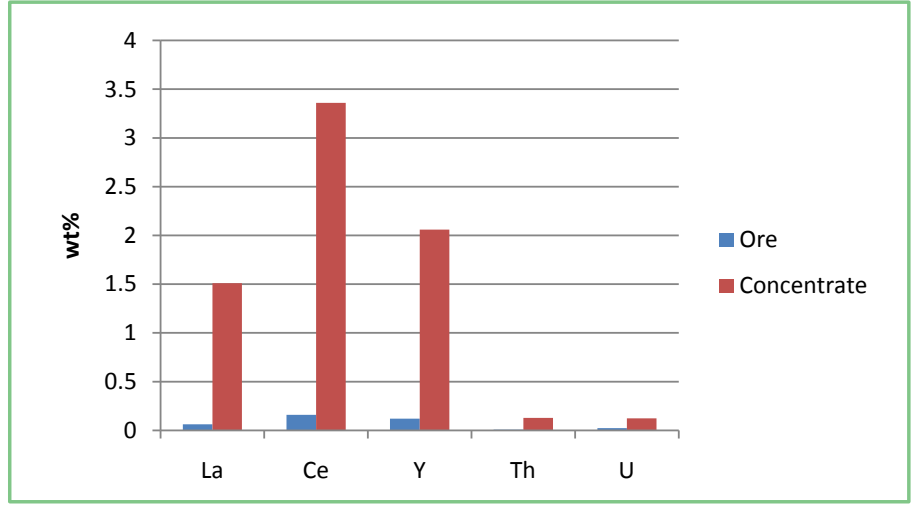

Figure 5. Significance of concentration of REE (La, Ce, Y) and radioactive elements $\mathrm{Th}$ and $\mathrm{U}$. 


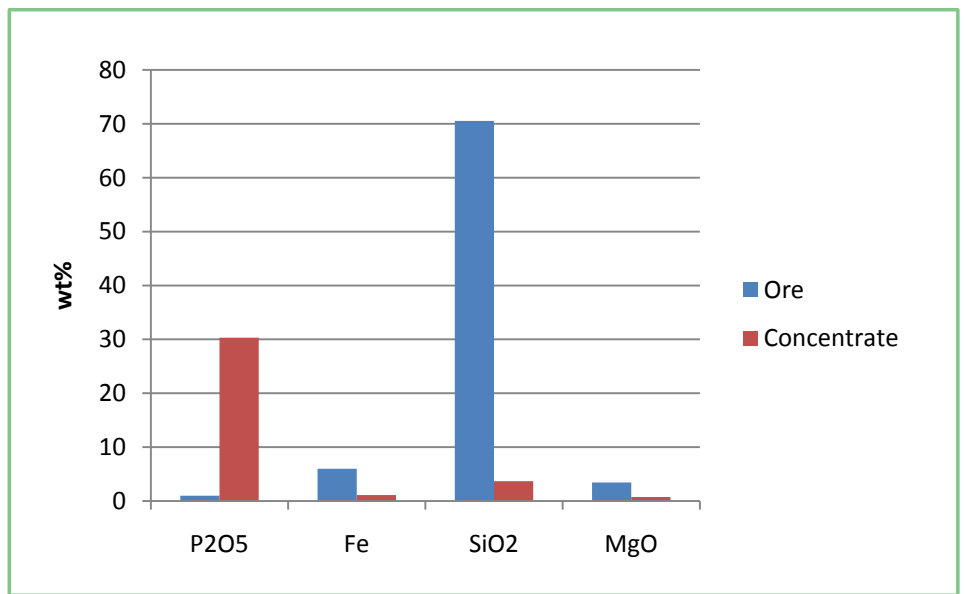

Figure 6. Significance of concentration of $\mathrm{P}$ and removal of $\mathrm{Si}, \mathrm{Fe}$ and $\mathrm{Mg}$.

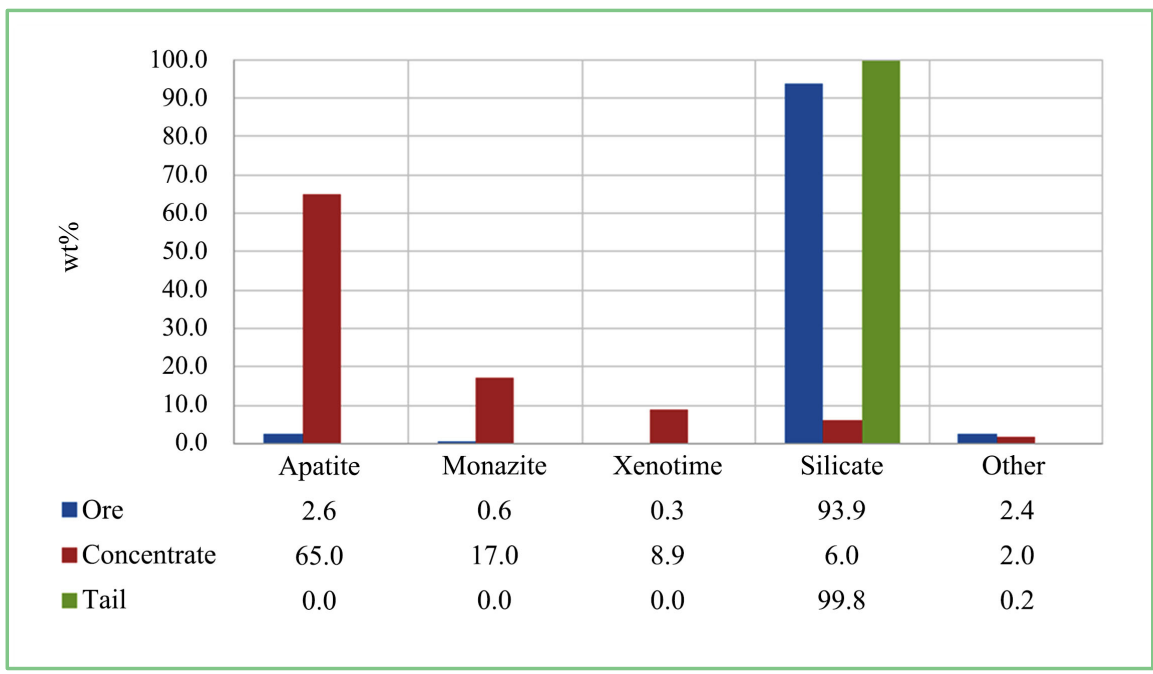

Figure 7. Mineral grades of apatite, monazite, xenotime, silicate and others in the ore, concentrate and tailing.

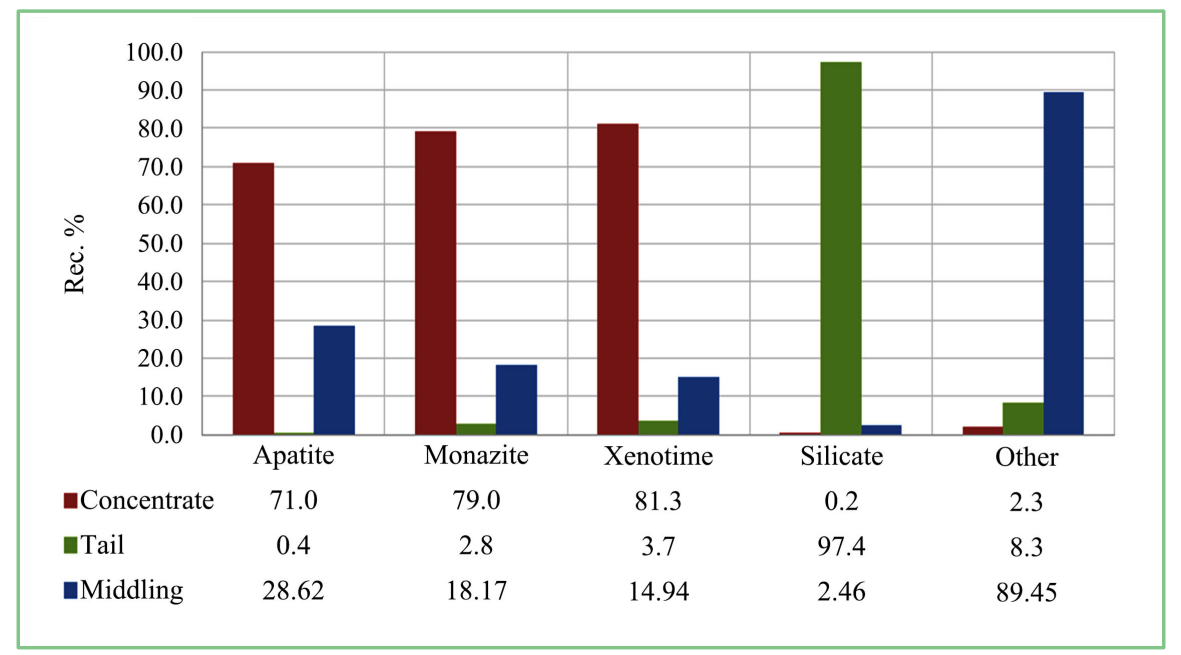

Figure 8. Mineral recoveries of apatite, monazite, xenotime and others in the concentrate, tailing and middling. 


\section{Conclusions}

Chemical analyses show that the content of REEs in the Olserum composite ore is $0.54 \%$ and the rate of heavy REEs is $37 \%$. Four minerals were identified by MLA and EPMA to bear REEs, including two phosphate minerals monazite-(Ce) and xenotime, one silicate mineral allanite, and one niobium oxide mineral pyrochlore. Monazite and xenotime are major REE-bearing minerals and carry $68.5 \%$ and $28.4 \%$ of the REEs in the ore, respectively.

The developed beneficiation flowsheet for the Olserum composite sample includes grinding, wet low intensity magnetic separation (WLIMS) for removal of magnetite and REEs flotation consisting of one stage of roughing and two stages of cleaning. Aero 6494 is more selective than other tested collectors for the flotation of REEs. REE-phosphates display very good flotation behavior in the grinding size range of (P80) $75 \mu \mathrm{m}$ to $180 \mu \mathrm{m}$. As the grinding size increasing the REEs ( $\mathrm{La}, \mathrm{Ce}, \mathrm{Y}$ ) grade of REEs concentrate increases but the recovery decreases.

Characterizations of REEs concentrate and tailings show that REEs, radioactive elements Th and $\mathrm{U}$, and phosphorus (measured by $\mathrm{P}_{2} \mathrm{O}_{5}$ ) were significantly enriched in the REEs concentrate and $\mathrm{Fe}, \mathrm{Si}$ and $\mathrm{Mg}$ as impurities were significantly removed. Monazite and xenotime were effectively enriched and silicates as the gangues were removed to the tailings. Although both monazite and xenotime had high recoveries (around 80\%) in the concentrate significant amounts of them $(14 \%-18 \%)$ were lost into the middling or the cleaning tailings. Further recovery of monazite and xenotime from the middling by flotation would be challenging because of high concentrations of oxides and high associations of monazite and xenotime with these minerals.

\section{Acknowledgements}

The authors are grateful to the European Community's Seventh Framework Programme (FP7/2007-2013) for the financial support.

\section{Conflicts of Interest}

The authors declare no conflicts of interest regarding the publication of this paper.

\section{References}

[1] EURARE (2017) REE Mineralization in Sweden. http://www.eurare.eu/countries/sweden.html

[2] Andersson, S.S., Wagner, T., Jonsson, E. and Michallike, R.M. (2018) Mineralogy, Paragenesis, and Mineral Chemistry of REEs in the Olserum-Djupedal REE-Phosphate Mineralization, SE Sweden. American Mineralogist, 103, 125-142. https://doi.org/10.2138/am-2018-6202

[3] Tasman Metals Ltd. (2013) Tasman Submits Mining Lease Application over Olserum Heavy Rare Earth Element Project, Sweden. https://www.globenewswire.com/news-release/2013/07/23/1381522/0/en/Tasman-Sub mits-Mining-Lease-Application-over-Olserum-Heavy-Rare-Earth-Element-ProjectSweden.html 
[4] Howie, R.A., Zussman, J. and Deer, W. (2013) Introduction to the Rock-Forming Minerals. 3rd Edition, Mineralogical Society, Chantilly.

[5] Pouchou, J.L. and Pichoir, F. (1986) Basic Expression of "PAP" Computation for Quantitative EPMA. 11 th International Congress on X-Ray Optics and Microanalysis (ICXOM), London, 4-8 August 1986, 249-253. 